\title{
The Causes of School Dropout: State of the Art
}

\author{
Júlia Angélica de Oliveira Ataíde Ferreira ${ }^{\# 1}$, Layde Dayelle dos Santos Queiroz ${ }^{* 2}$, Ronison Oliveira da \\ Silva $^{* 3}$, Márison Luiz Soares ${ }^{* 4}$, Daniel Nascimento-e-Silva ${ }^{\# 5}$ \\ ${ }^{\#}$ Federal Institute of Education, Science and Technology of Amazonas \\ Avenida 7 de Setembro, 1975, Centro, 69020-120 Manaus, Amazonas, Brazil
}

\begin{abstract}
In the educational context, one of the biggest problems that affect the performance of school institutions is what concerns dropouts. This study aims to describe the state of the art of school dropouts. It considered that the decision of students to interrupt their training itinerary brings adverse effects not only for the subject who evades since the magnitude of this problem causes damage to the whole society. The method used was the conceptual bibliographic submitted by Nascimento-e-Silva (2012; 2020), which consists of four phases: a) definition of research questions; b) data collection; c) organization and analysis of data, and; $d$ ) generation of responses. The study inferred that among the causes detected in the consulted literature, there are both causes relevant to the personal scope of students who drop out and the causes related to the education system and how education is organized from an institutional point of view. The conclusion shows that the school institutions need to constantly observe what science produces about dropout, to strengthen themselves in terms of managing and controlling the causes that support the phenomenon of dropping out of school.
\end{abstract}

Keywords - Student dropout, Dropout causes, Quality in education, Types of dropout causes, School dropout.

\section{INTRODUCTION}

One of the main problems that affect professional and technological education institutions (EPT) is a school dropout. With the creation of the Federal Network of Professional, Scientific and Technological Education (Brasil, 2008), several young people in Brazil were able to have the opportunity to enhance their training through courses offered at Federal Institutes (IFs). Data from the Nilo Peçanha Platform shows that the annual dropout rates in higher education courses at Federal Institutes have the following percentages: 2017, 17.\%; 2018, $14.5 \%$ and 2019, 12.7\%. Despite the notable decrease, school dropout still represents an obstacle overcome by educational institutions (Souza \& Freitas, 2021).

Education represents the opportunity that people have to improve the curriculum and add knowledge and, through this learning, contribute to their respective living environments (Andrade, 2016). However, when a student drops out, the losses generated are not restricted to the subject who decides to abandon their studies. In the specific case of students whose families have an unsatisfactory social and financial situation, dropout represents the failure to take advantage of the opportunity, through studies, to improve their family's living conditions. The community to which the evaded student belongs also loses, as the knowledge learned in the classroom may lead to social initiatives and technologies that can improve, whether in the educational, social, or environmental aspect, the lives of their fellow citizens (Silva \& Nascimento-e-Silva, 2020a).

In this context, the study of the causes of dropout is necessary for two reasons, according to the logical scheme proposed in the studies by Oliveira (2019), Silva (2019), and Souza (2020). The first one is theoretical and aims to understand the diversity of reasons that can lead a student to decide not to continue his training itinerary. The generation of this knowledge is necessary for social workers, teachers, pedagogues, course coordinators, and other actors involved to understand the logic underlying each factor that culminates in school dropout. It is worth emphasizing that the generation of this knowledge needs to observe the methodical and systematic character that affects all scientific research to ensure its credibility and reliability (Capocasa \& Volpi, 2019; Ketokivi \& Choi, 2014).

The second reason is practical and generates support for the decision-making process of professionals who deal directly with school dropouts. According to current legislation (Brasil, 1996), the management of pedagogical spaces must be practiced under the aegis of participation (Borges, Silva \& Nascimento-e-Silva, 
DOI: $\underline{10.51386 / 25815946 / \mathrm{ijsms}-\mathrm{v} 4 \mathrm{i} 4 \mathrm{p} 127}$

Volume: 4 Issue: 4

July to August 2021

https://www.ijsmsjournal.org

2020; Valle, Nascimento-e-Silva \& Silva, 2020). It means that all actors participating in this process have the prerogative to make deliberations and assume the consequences of their decisions taken in a collegiate manner. However, for this process to be assertive, it is necessary to have information that can show decision-makers the actual degree of problems to adopt the best solutions. Investigating the causes of dropout from a pedagogical perspective is needed to detect the root causes that lead the student to drop out. It may be associated with personal problems or have some relationship with the school institution, whether structural or pedagogical (Dore, 2013).

As it is a complex problem, school dropout needs to be analyzed from a managerial point of view. In this sense, it is opportune to highlight what Nascimento-e-Silva (2017) said about registrations in science and technology organizations: everything must be registered. This maxim is not followed in its entirety by the Class Councils. The reasons that lead the student to drop out are not always included in the records of this collegiate body. It considers that school institutions, especially EPT, coexist in a truly dynamic performance environment (Kanan \& Zanelli, 2011). Thus, the solution to the problem of management involves adopting control instruments that can reduce the level of uncertainty usually associated with the reasons that lead a student to drop out of studies.

Nascimento-e-Silva et al. (2013) and Silva et al. (2019) clarify that control is the managerial function responsible for comparing the planned and the produced during the making of a given plan. When the planning does not go according to expectations, the points where the work performed was deficient are corrected. This same logic applies to truancy. Everything registered in the Pedagogical Course Projects (PPC) must be duly monitored, including comparing the number of students enrolled and approved. The constant monitoring of the causes of dropout, followed by the adoption of consistent strategies to face this problem, is one of the structuring axes for achieving quality in education (Alavarse, Bravo \& Machado, 2013).

This study aims to describe the state of the art regarding causes of school dropout. The intention to realize this textual construct is to discover what the content of scientific studies brings about the factors that can trigger school dropout. In addition to the reasons, it considered that the need to proceed with this research lies in the fact that school dropout is a problem of national magnitude, which causes damage not only for the student but also for society. Given the importance of the topic, it expects that this will help EPT students, especially students of professional master's degrees in education, devise technological solutions that help combat dropout. At the same time, there is an expectation of clarifying all education professionals who deal with this problem to broaden their vision regarding the causes of school dropouts in their respective institutions.

We used the conceptual bibliographic method submitted by Nascimento-e-Silva $(2012 ; 2020)$ to realize this research. It is a set of writing techniques composed of four steps: a) definition of research questions, b) data collection, c) organization and analysis of data, and d) generation of responses (Nascimento-e-Silva, 2020; Silva; Nascimento-e-Silva, 2020b). The performance of these procedures generated a particular grouping of causes, organized into figures and reference tables, to facilitate the understanding of the similarities and differences present in each definition found.

\section{THE CAUSES OF DROPOUT}

We emphasized that the causes of dropout can be understood under two approaches. The first one is called individual, which can also be called micro. In this perspective, the possible causes have the student at heart. It inferred that causes of a personal, financial or psychological nature are in the group of reasons that lead a student to drop their studies. The second focus is called macro or institutional, exemplified by the causes of the school institution's education system, or even its structure and evaluation methods (Dore, 2013). Figure 1 demonstrates the causes of dropout found during research practice. 
DOI: $\underline{10.51386 / 25815946 / \mathrm{ijsms}-\mathrm{v} 4 \mathrm{i} 4 \mathrm{p} 127}$

Volume: 4 Issue: 4

July to August 2021

https://www.ijsmsjournal.org

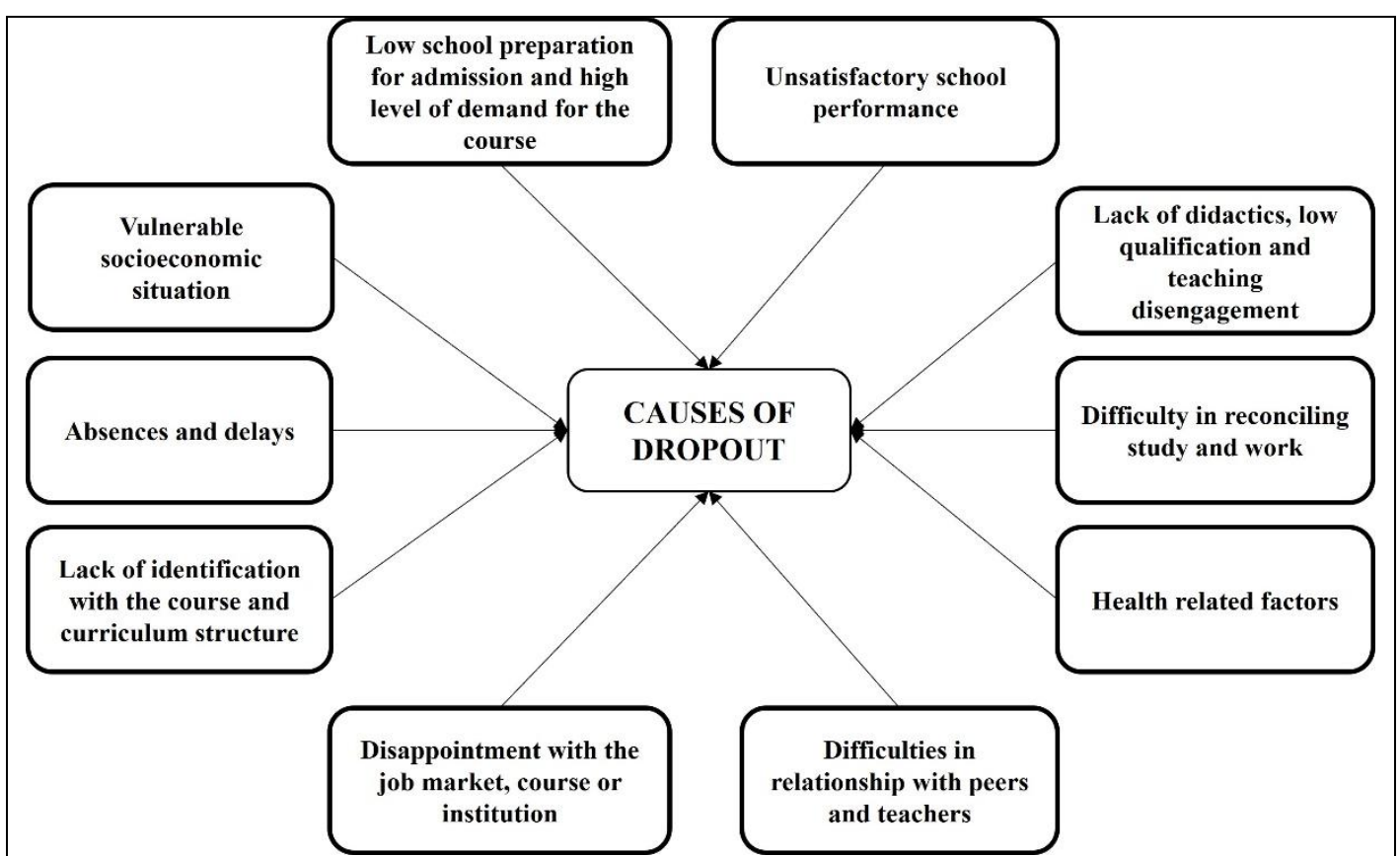

Figure 1. The causes of dropout.

Source: Prepared by the authors.

Figure 1 demonstrates a logical scheme to summarize the dropout causes in each subsection that integrates this part of the present study. Nascimento-e-Silva (2017) clarifies that logical schemes can be understood as drawings that facilitate understanding a particular theme or subject. In the specific case of Figure 1, the core of the present textual construct appears in the center of the image. It shows that the research practice allowed identifying causes related to the micro perspective of analysis proposed by Dore (2013), as the difficulty related to peers, lack of identification with the course and curriculum structure, and health-related factors. Figure 1 also allowed detecting causes of dropout associated with the teaching-learning processes, such as the lack of didactics, low qualifications, and disengagement from teaching, which is an institutional problem according to Dore (2013). The details regarding each cause are in the following subsections.

\subsection{Vulnerable socioeconomic situation}

Kowarick (2003) defines vulnerability as a political-democratic issue generated by denying fundamental rights to the impoverished population, such as income, education, health, food, water, and housing. In a similar definition, Monteiro (2011) says that social vulnerability is a concept under construction that has developed in recent decades, moving from its purpose of economic deficiency to exposure to risks of different types, such as health, culture, and education. The concept covers a person or a social group depending on their ability to prevent, resist and circumvent potential impacts. Thus, living and living is a way to measure vulnerability and the conditions for insertion in work, access to essential health and education services.

Lisboa (2015) elucidates that the Institute for Applied Economic Research (IPEA), in partnership with the United Nations Development Program (UNDP), prepared the Social Vulnerability Index (SVI) in a broader perspective of understanding poverty situations, including information on well-being, linked to the issue of insufficient income. The proposal aims to map exclusion and vulnerability. One of the main contributions of the index is that it is a tool that supports the elaboration of public policies according to territorial needs. It supports the development of actions by municipal, state, and federal administrations.

With the collaboration of partner entities, IPEA developed the Atlas of Social Vulnerability of Brazil. The data from the vulnerability block of that atlas were the pillar for the creation of the SVI. The atlas comprises sixteen measurement indicators, grouped into three-dimensional blocks: urban infrastructure, income and labor, and human capital. The indicators, calculated from demographic census variables, are distributed as shown the table I, according to Lisboa (2015). 
DOI: $\underline{10.51386 / 25815946 / \mathrm{ijsms}-\mathrm{v} 4 \mathrm{i} 4 \mathrm{p} 127}$

Volume: 4 Issue: 4

July to August 2021

https://www.ijsmsjournal.org

TABLE 1

VULNERABILITY INDICATORS

\begin{tabular}{|l|l|l|}
\hline Urban infrastructure & Human capital & Income and work \\
\hline Basic urban services: sanitation & Health (of children and maternal, especially) & Child labor \\
\hline Basic urban services: water & $\begin{array}{l}\text { School trajectory of children and young } \\
\text { people }\end{array}$ & Informality \\
\hline Basic urban services: sewage & Education of the adult population & Vacancy \\
\hline $\begin{array}{l}\text { Basic urban services: garbage } \\
\text { collection }\end{array}$ & $\begin{array}{l}\text { Vulnerability of women - the female head of } \\
\text { the family, with low education and underage } \\
\text { children }\end{array}$ & $\begin{array}{l}\text { Young people who neither } \\
\text { work nor study }\end{array}$ \\
\hline Urban mobility & Teenage pregnancy & Income \\
\hline \multicolumn{2}{|c|}{ Child mortality } & \\
\hline
\end{tabular}

The methodology for building the SVI is organized in these three dimensions and the spatial division. Each of these dimensions of indicators has equal weight. Therefore, the SVI is the result of the sum of the impact of the dimensions. Spatially, the indicator value measures a ruler from 0 to 1 , with 0 being the best result and one being the worst. The ruler has five ranges: Very Low SVI, Low SVI, Medium SVI, High SVI, and Very High SVI. With the result and the indicators, it is possible to see which dimensions are more vulnerable and develop public policies to improve this specific dimension (Lisboa, 2015).

Brazilian researchers such as Deschamps (2004, 2006), Alves et al. (2010a), Almeida (2010), and Silveira (2010) work with the definition of vulnerability indicators in the economic, social, and environmental dimensions to measure vulnerability. Factors such as income distribution, work informality, and economic segregation by race and gender are considered in the economic dimension. In the social dimension: head of the family, number of dependents, ethnicity, and level of education of family members. In the environmental dimension, aspects related to infrastructure include sanitation, garbage collection, and water supply. These indicators are consistent with those used for SVI.

In the educational field, this survey used a socioeconomic questionnaire. Such a survey instrument should compose the measurement above variables, translating into a paradigm shift in the definition of vulnerability, which in significant part is measured only by family income. Given this, it will be possible to estimate how much this cause, vulnerability, has interfered with student dropout by crossing school attendance data with the information provided in the socioeconomic questionnaire. In the light of the SVI, it is still possible to group these variables into three groups and infer weights of scores, to define the degree of vulnerability to which this individual is submitted, being able to follow the pattern shows in table II.

TABLE II

PARAMETERS FOR CALCULATING THE SVI

\begin{tabular}{|l|l|}
\hline \multicolumn{1}{|c|}{ Index } & \multicolumn{1}{c|}{ Level of socioeconomic vulnerability } \\
\hline $1,0-0,81$ & Very high \\
\hline $0,8-0,61$ & High \\
\hline $0,6-0,41$ & Medium \\
\hline $0,4-0,21$ & Short \\
\hline $0,2-0,0$ & Very low \\
\hline
\end{tabular}

Source: Adapted by the authors based in Lisboa (2015).

Thus, considering the common indicators presented here, we can state that socioeconomic vulnerability is detected when low access to basic sanitation, garbage collection, and drinking water permeate the individual or family. When you have women head of the family, the difficulty in providing for the dependents while needing to meet other social needs - the low level of education, low income, and informality at work.

\subsection{Unsatisfactory school performance}

School performance is the ability of students to express the knowledge acquired in the teaching-learning process (Nha \& Yen, 2021). According to D'Abreu and Marturano (2010), when the student in front of an 
DOI: $\underline{10.51386 / 25815946 / \mathrm{ijsms}-\mathrm{v} 4 \mathrm{i} 4 \mathrm{p} 127}$

Volume: 4 Issue: 4

July to August 2021

https://www.ijsmsjournal.org

evaluation process or even in everyday school activities results below the expected age, ability, or potential, there is low school performance.

Research indicates that school facilities and resources have a relatively small or moderate impact on students' academic performance in carrying out a literary review. Fernandes et al. (2018) show that in a survey conducted by (Tomé \& Matos, 2012), adolescents, for example, who have more contact and a good relationship with their parents, are happier, more satisfied with life tend to perform at school. The findings show that the factors associated with learning from the student himself and his family group are the ones that exert the most significant influence.

Palermo et al. (2014), when reflecting on the theme of low academic performance of students and its associated factors, point out self-esteem problems as one of the leading causes and effects of the pain. Nascimento -e-Silva (2019) emphasizes that the lack of confidence in oneself and their chances of success can lead to a block in learning. Another aspect to consider for performance is the student's educational trajectory, as a history of repetition and dropout influences their self-esteem. Students who have already failed show a feeling of failure, feel less motivated, and have less perspective on continuing their studies and the future, being more likely to drop out. Deficits in some basic processes can constitute obstacles to developing superior strategies (Tonelotto et al., 2005).

It highlighted as a motivating factor for self-esteem concerning school performance, parents' interest in their children's education, and the supervision they exercise in the student's school life through incentives, presence at school, and conversations about everyday school life. Furthermore, according to Soares (2005), Gonçalves et al. (2010), and Machado et al. (2008), the greater the cultural capital of the family, the greater the probability of good student performance. We can use it as a related item to unsatisfactory school performance, the following measurement variables, shown in Table III. It is as a guideline the aspects pointed out. Based on the understanding that what is sought with this work is not to measure the students' school performance but to act on the causes that can generate unsatisfactory performance.

TABLE III

VARIABLES TO MEASURE POOR SCHOOL PERFORMANCE

\begin{tabular}{|l|l|}
\hline \multicolumn{1}{|c|}{ Variables } & \multicolumn{1}{c|}{ Measurement } \\
\hline Cultural capital level & $\begin{array}{l}\text { Years of study + parent/guardian reading habit + parent/guardian incentives } \\
\text { for the student to study at home }\end{array}$ \\
\hline Repetition level & $\begin{array}{l}\text { It is the sum of the number of times the student failed and dropped out of } \\
\text { school during class time and stayed out of school the rest of the year }\end{array}$ \\
\hline $\begin{array}{l}\text { Level of participation in } \\
\text { school life }\end{array}$ & $\begin{array}{l}\text { How often guardians go to parents' meetings + Parents' encouragement for } \\
\text { their children to read + Incentives for them to study + Incentives to do } \\
\text { activities at home + Incentive not to miss classes + If guardians talk to their } \\
\text { children about what happens at home school }\end{array}$ \\
\hline
\end{tabular}

Source: Prepared by the authors.

Fernandes et al. (2018) highlight that school difficulties, including failure, favor the emergence of behavioral and emotional problems, producing disbelief in teachers, parents, and students themselves regarding their ability to learn. However, suppose failures negatively affect school performance. In that case, students' social skills and family support, teachers, and peers can act as a protective factor, unlike what happens in a context of low grades associated with limited family support (Dias et al., 2015). Thus, the more social support students have, the more quickly they face the school path's challenges (Machado et al., 2014).

\subsection{Difficulty in reconciling study and work}

The work occupies an ample space in the youth's imagination. Demographic and attitudinal surveys show that work is the topic of most significant interest and concern for youth. However, there is controversy in the literature around the positivity or negativity of work insertion in youthhood. Some believe that work can harm studies and contribute to school dropout and others believe it can help with school permanence and motivation to study (Mattos \& Chaves, 2010; Martadiani, Aziz \& Widari, 2021). 
DOI: $\underline{10.51386 / 25815946 / \mathrm{ijsms}-\mathrm{v} 4 \mathrm{i} 4 \mathrm{p} 127}$

Volume: 4 Issue: 4

July to August 2021

https://www.ijsmsjournal.org

Thomas et al. (2016) bring a collection of research that points to positive and negative factors regarding the employment of young students. Among the positives that stand out: growth of young people as people and citizens; establishment of references with bosses and co-workers, encouraging them to seek higher education and overcome problems such as involvement with illegal drugs and marginality; development of social and technical skills; assistance in choosing a professional career. On the negative side, the following stand out tiredness due to the high number of hours spent studying and working. It starts to sleep less and have less time for leisure; frustration for not learning as they would like, especially outside the classroom, can influence their academic performance and permanence in the course.

The impact of the difficulty in reconciling study and work on dropout needs to be measured, taking into account the student's subjectivity. Since it is consensual in the literature that working simultaneously as studying produces a physical and mental burden on the student, it is up to him to assimilate this dynamic in a motivating way, with a view to an ascent via education or demotivating. Therefore, the proposal for measuring this cause is to conduct interviews with students to measure the extent to which reconciliation is a leading factor in dropping out of the course. The institutional strategies can minimize the problem based on what will be brought up in the hearing, such as optimizing time in the classroom to carry out exercises and activities to the detriment of carrying them out in extra-class periods.

\subsection{Teachers with inadequate methodology, low qualification, and disengagement}

Several elements are essential in the strategic organization of the work environment. Faria et al. (2017) highlight interpersonal relationships, participation in management, respect for people, and valuing the efforts of workers to solve problems. Engagement, according to them, based on (Lhuilier, 2014), from the perspective of the psychosociology of work, is to work motivated by values or causes in which one believes, being beneficial to workers by causing them well-being. The expression engagement can include involvement, commitment, ownership, feeling valuable.

The teacher expects a diversity and complexity of knowledge and activities beyond teaching and research and encompasses communication, flexibility, critical thinking, creativity, construction of values and social interaction, etc. (Tiecher, 2019). Engagement diagnoses are good tools for measuring motivation and satisfaction levels, identifying strengths and weaknesses under the employee's bias. Ideally, it should be applied by a specialist in the area, external to the institution, crossing qualitative and quantitative data.

As the teacher's practice develops at school, his professional improvement leads to the institution's advancement and vice versa (Almeida, 2004). It is up to this professional to use interlinked and connected teaching strategies, which provide meaning to the contents taught and instigate students to research, problematize, create, in short, learn. For Anastasiou, Cavallet and Pimenta (2003), teacher planning allows the organization of content/knowledge systematically, allowing students to establish connections with their previous knowledge and assign personal meaning to what they learn. The greater the number of students involved in this practice, the more democratic the teaching. This process consists of a complex social method, socially determined and at the same time unique, differentiated by the individual interpretations and emotions raised.

Under the student's bias, especially to measure the methodology and teaching qualification, it is possible to integrate a web research system into the academic management system. It would allow sending specific questionnaires by discipline, class, or course, providing opportunities for assessing disciplines and their respective professors. It needs to know about issues as a) the quality of content and its relevance, b) if the subject presupposes prior knowledge that the student did not have; if the discipline overlaps with others in the same course, c) if the methodology used was adequate, d) whether the speed of introduction of new concepts was adequate, e) if the practical activities were enough for learning, f) if the teacher starts and finishes classes on time, g) if the teacher demonstrates mastery of the content, and h) if the teacher answers the questions.

\subsection{Absences and delays}

Absenteeism is from the Latin absens, which means to be out, away, or absent. The expression expresses the lack of attendance and the typical delay in the school context, culminating in the student's absence from school for abstaining from their activities. Knowing the reasons for absences is necessary to determine if they are consequences of internal or external factors and then act on them. So, the student must ask through a conversation with the pedagogical team of their course. 
DOI: $\underline{10.51386 / 25815946 / \mathrm{ijsms}-\mathrm{v} 4 \mathrm{i} 4 \mathrm{p} 127}$

According to Pinheiro (2007), we can state, due to this attendance problem, other aspects of the teachinglearning process will also be compromised, such as interaction with the class and teachers, contextualized monitoring of the content taught, resolution of doubts, etc. The LDB, Chapter II, art. 24, item VI ensures that "[...] the control of attendance is the responsibility of the school, as provided for in its charter and the rules of the respective education system, requiring a minimum attendance of seventy-five percent of the total hours for approval [...]" (Brasil, 1996). Schools need to have educational systems that calculate attendance as a percentage compared to the number of hours/classes taught to measure student absenteeism. However, results can only be seen and prevention actions taken if each teacher frequently performs the frequency input in the system.

\subsection{Lack of identification with the course and curriculum structure}

In the daily professional practice, we often empirically perceive that when they realize that they acted driven by expectations adverse to personal anxieties, students feel discouraged and seek to change courses, sometimes culminating in dropouts. The desire to abandon a course to seek another one is usually due to a lack of information about the course, especially its curricular structure. These frequent motivations are often: the family's desire for the student to graduate in such a course, whether at a technical or undergraduate level, the social recognition of the profession that comes with a diploma, greater employability for professionals specialized in a specific area, referral of friends, less competition, etc.

Andriola (2009) points out that the change of course in Brazilian universities is alarming and not only signals mistakes in professional guidance. It also represents a burden for society due to the undue occupation of such scarce places, especially in public institutions, and their financial waste. One of the possible ways to measure the student's identification with the course is by completing vocational tests. This vocational guidance process cannot be carried out without professional monitoring to avoid losing its quality. Its objective is to help young people get to know themselves better, giving them subsidies to make the most appropriate choice. It defines how the individual chooses and prepares to enter and progress in an occupation (Dantas \& Lima, 2017).

An exciting strategy used in this matter is creating extracurricular activities to have more contact with the profession at the beginning of the course when they are taking introductory courses. Inform students entering the 1 st module or year, in the integration, in a clear way, the course's objectives and the role of the professional of the corresponding course in the labor market. Elementary and high schools can carry out professional guidance to work on the transition process even before entering the institution. Federal institutes and universities can publicize courses, curricular structures, and perspectives on the job market for students in the public and private education network to elucidate their choice before entering higher education or technician. It can also offer lectures on its structure, functioning, offer, and installation.

\subsection{Low school preparation for admission and high level of demand for the course}

The elementary school or high school diploma is not synonymous with the student's sufficient skills to enter the subsequent teaching modality, creating difficulties in adapting and monitoring the course. Taking a test is also not a consensus in the literature as the acceptable way to measure the knowledge acquired in the student's education. Studies show that the higher the failure rate in subjects, the more likely the student will drop out in that teaching cycle. As the student progresses, dropout becomes smaller, probably due to a greater interest in the disciplines and a consolidation of their professional choice.

Therefore, international examples can be used as a parameter to measure school preparation for entering the course. In the United States, we have the example of the SAT (Scholastic Assessment Test). Several faculties use it to measure student preparation for the classes that will be taught. Performance is not assessed as 'pass' or 'fail' but with a score. The higher the score, the more likely it is to be accepted by the institution. It is usually carried out after finishing high school, but adaptations can also be applied at elementary school. Its application is not in a single test, as done in Brazil through the national high school exam (ENEM), but in seven tests during the last one in the school. Also, in the United States, we can list the American College Testing (ACT). It is a standardized admission test for universities administered between four and six times a year and divided into five subjects.

\subsection{Health-related factors}

Health is an essential condition for good learning. The moment of knowledge requires a series of favorable conditions from the organism, whether nutrition, hygienic care, good vision, posture, or emotional support. The 
DOI: $\underline{10.51386 / 25815946 / \mathrm{ijsms}-\mathrm{v} 4 \mathrm{i} 4 \mathrm{p} 127}$

Volume: 4 Issue: 4

July to August 2021

https://www.ijsmsjournal.org

environment also needs to be conducive, with lighting, living areas, drinking water, good storage and disposal of waste, adequate sanitary facilities, and other structural problems that ensure the healthiness of the educational space and that it provides a good learning environment.

An overview of the student's health must be made at the entry to measure students' health. This investigation may include: 1 - Interview with parents (if underage) or with the student himself about his general health condition, 2 - Nutritional assessment, 3 - Monitoring of immunizations, 4 - Psychological Test, 6 - Exams Medical and Dental, performed by members of the existing multidisciplinary team in the case of institutions that have it, or in partnership with the community's Basic Health Unit.

\subsection{Difficulty in relating to peers and professors}

Affectivity permeates human sociability. Studies have shown that interpersonal interaction plays an essential role in the development and learning of students. Most of these studies have mainly emphasized the teacherstudent relationship and, to a lesser degree, significantly the relationship between peers. The teacher's relationship with other school members is essential for the educational work to be complete and the act of teaching to reflect a pleasurable act. For Freschi and Freschi (2013, pp. 2), "Being a good professional does not only mean communicating well and knowing specific contents, but it is also important to realize the importance of affection and the formation of values for the personal growth of individuals."

In this sense, Saltini (2008) reports that the exchange of information occurs through dialogue. It happens through the interaction between the student and the teacher, and their classmates. Everyone develops intellectually in the interaction of the proposed activities. When the student feels in the teacher's eyes that they are welcome, recognized, and learning is sharing and interacting with different ways of thinking and saying, the world becomes autonomous and learns to build their knowledge.

Studies on rejection were conclusive in stating that it predisposes to poor school performance and conduct disorders at school, in family, and the social environment. Tonelotto (2012) uses the student's attitudes towards peers scale to measure the student's relationship with his peers, how he feels towards them and how he believes his peers see him. The results of applying the questionnaire are analyzed item by item, using factor analysis.

\subsection{Disappointment with the job market, course, or institution}

Whether it is a medium or higher level, the choice for a course is a complex task, permeated by uncertainties and anxieties. In capitalist societies, such as the one we live in, there is a social overvaluation of the labor activity that human beings perform. Therefore, this choice permeates all this socially rooted cultural aspect. Even after the options, doubts persist during the training period. Diogo et al. (2016) point out that the more aware of the professional world and the knowledge mentioned above of the course and its curricular structure, the more consistent and secure students' choices.

Among the reasons that influence the choice of the course are aptitude, vocation, and affinity; personal achievement and personal projects; curiosity and affinity for the subject; promising job market; complementation of professional career; the profession itself; family influence; and the desire to continue studying. The reasons that negatively influence the permanence are a) course complexity, overload of activities, fear and nervousness caused by teachers (Arruda \& Ueno, 2003); b) unfavorable market, discontent, and disinterest in the course, personal factors such as frustration, insecurity, indecision, and disappointment (Bardagi, Lassance \& Paradiso, 2003); c) difficulty in financing studies and feelings of not belonging to the group (Zago, 2006); d) change of opinion about the course, lack of self-knowledge (not knowing what you want and what you like), and e) pressure from family and colleagues to finish the course.

Recognition of the devaluation of the profession can contribute, in the decision-making process, to drop out, with feelings of inferiority, breach of expectations, and loss of enthusiasm for the professional future. According to Melo and Borges (2007), young people resort to other strategies when faced with the difficulty of insertion. One of them is completing a new undergraduate course, jobs with lower pay to acquire experiences, and often, occupation in positions that are not compatible with their training. Faced with so many subjective possibilities, the best way to measure disappointment with the course, institution, or job market is to listen to students through a pedagogical team. 
DOI: $\underline{10.51386 / 25815946 / \mathrm{ijsms}-\mathrm{v} 4 \mathrm{i} 4 \mathrm{p} 127}$

Volume: 4 Issue: 4

July to August 2021

https://www.ijsmsjournal.org

\section{CONCLUSION}

This study aimed to describe state of the art regarding the causes of dropouts. The research practice allowed the detection of reasons related to the individual perspective of this phenomenon and cataloged causes related to the teaching and learning process under the institutional focus. The detailing of each cause made in the textual body of the study can support EPT institutions to create control mechanisms with the reasons presented in this study serving as structuring axes. It facilitates the management of dropout, which requires creating innovative solutions that can help face the setbacks created in this context in which students decide to abandon their studies.

The more profound the study of the causes of dropout, the better EPT institutions will become to develop the necessary strategies to overcome this problem. It is essential to clarify that this research does not represent an end in itself. It is vital to encourage more in-depth studies on the causes of school dropout. In the case of Brazil, due to its continental dimensions, it means that each geographic region has specific realities and can influence the dropout panorama.

Regardless of the approach adopted in carrying out these suggested studies, it is convenient to confront the confrontation between the theory and its practice. This comparison is necessary so that these researches show the similarities and differences between the theoretical field and the daily life experienced by professionals who deal directly with dropouts when dealing with their tasks in EPT institutions. The divergences found in these studies may inspire the conduct of research to understand more deeply why these differences exist. The encouragement of scientific production focused on the cause-effect relationship that affects the factors that culminate in dropout school.

EPT institutions must strive to understand the causes that lead their students to interrupt their training cycle with greater precision. It is necessary because the lack of knowledge of these causes means that these knowledge organizations are left without the necessary guidance to know what to do to overcome the harmful effects generated by school dropouts. With reliable information, plans and strategies can be drawn up to reduce dropout rates and improve the quality of education. As a dominant factor for this, the constant monitoring of scientific production regarding the causes of dropout becomes essential since a problem cannot be solved without precisely knowing the reasons that corroborate its existence.

\section{REFERENCES}

[1] Alavarse, O. M., Bravo, M. H., \& Machado, C. (2013). Avaliações externas e qualidade na educação básica: articulações e tendências. Estudos em Avaliação Educacional, 24(54), 12-31. https://doi.org/10.18222/eae245420131900

[2] Almeida, L. Q. (2010). Vulnerabilidade socioambiental de rios urbanos: bacia hidrográfica do rio Maranguapinho, região metropolitana de Fortaleza, Ceará. Unpublished PhD thesis, Universidade de São Paulo, Rio Claro, Brazil.

[3] Almeida. M. I. (2004). Docentes para uma educação de qualidade: uma questão de desenvolvimento profissional. Educar, (24), 165176. https://doi.org/10.1590/0104-4060.354

[4] Alves, H. P. et al. (2010). Dinâmicas de urbanização na hiperperiferia da metrópole de São Paulo: análise dos processos de expansão urbana e das situações de vulnerabilidade socioambiental em escala intraurbana. Revista Brasileira de estudos populacionais, 7(1), 141-159. https://doi.org/10.1590/S0102-30982010000100009

[5] Anastasiou, L. G. C., Cavallet, V. J., \& Pimenta, S. G. (2003). Docência no ensino superior construindo caminhos. In: Barbosa, R. L. L. (Org.). Formação de educadores: desafios e perspectivas. São Paulo, EdUNESP.

[6] Andrade, T. S. S. (2016). A importância da divulgação científica em processos formativos de professores no ensino tecnológico.Unpublished master thesis, Instituto Federal de Educação, Ciência e Tecnologia do Amazonas, Manaus, Brazil.

[7] Andriola, W. B., \& Andriola, C. G. (2009). Avaliação da qualidade educacional da Faculdade de Educação (FACED) da Universidade Federal do Ceará (UFC). Ensaio: Avaliação e políticas públicas em educação, 17(62), 153-168. https://doi.org/10.1590/S0104-40362009000100008

[8] Arruda, S. M., \& Ueno, M. H. (2003). Sobre o ingresso, desistência e permanência no curso de Física da Universidade Estadual de Londrina: algumas reflexões. Ciência \& Educação, 9(2), 159-175. https://doi.org/10.1590/S1516-73132003000200002.

[9] Bardagi, M. P., Lassance, M. C. P., \& Paradiso, A. C. (2003). Trajetória acadêmica e satisfação com a escolha profissional de universitários em meio de curso. Revista Brasileira de Orientação Profissional, 4(1), 153-166.

[10] Borges, N. S. C. S., Silva, R. O., \& Nascimento-e-Silva, D. (2020). Gestão participativa e participação em espaços pedagógicos: percepção dos integrantes de uma instituição de educação profissional e tecnológica. Interfaces da Educação, 11(32), 79-105. https://doi.org/10.26514/inter.v11i32.4204 
DOI: $\underline{10.51386 / 25815946 / \mathrm{ijsms}-\mathrm{v} 4 \mathrm{i} 4 \mathrm{p} 127}$

Volume: 4 Issue: 4

July to August 2021

https://www.ijsmsjournal.org

[11] Brasil. (1998). Constituição da República Federativa do Brasil. Brasília: Senado Federal.

[12] Brasil. (1996). Lei n.9.394 de 20 de dezembro de 1996. Dispõe sobre as diretrizes e bases da educação nacional. Brasília: Senado Federal.

[13] Brasil. (2008). Lei $n^{\circ}$ 11.892, de 29 de dezembro de 2008. Institui a Rede Federal de Educação Profissional, Científica e Tecnológica, cria os Institutos Federais de Educação, Ciência e Tecnologia, e dá outras providências. Brasília: Senado Federal.

[14] Capocasa, M., \& Volpi, L. (2019). The ethics of investigating cultural and genetic diversity of minority groups. J. Comp. Hum. Biol., $70(3), 233-244$.

[15] D'Abreu, L. C. F., \& Marturano, E. M. (2010). Associação entre comportamentos externalizantes e baixo desempenho escolar: uma revisão de estudos prospectivos e longitudinais. Estudos de Psicologia, 15(1), 43-51. https://doi.org/10.1590/S1413294X2010000100006.

[16] Dantas, G. O., \& Lima T. C. (2017). Orientação vocacional de adolescentes em situação de escolha através da abordagem clínica de Rodolfo Bohoslavsky. Revista científica multidisciplinar Núcleo do conhecimento, 14(2), 5-21.

[17] Deschamps, M. V. (2004). Vulnerabilidade socioambiental na região metropolitana de Curitiba. Unpublished PhD thesis, Universidade Federal do Paraná, Curitiba, Brazil

[18] Dias, A. et al. (2015). Percepção dos alunos acerca das estratégias de promoção do sucesso educativo e envolvimento com a escola. Estudos de Psicologia, 32(2), 187-199. https://doi.org/10.1590/0103-166X2015000200004.

[19] Diogo, M. F. et al. (2016). Percepções de coordenadores de curso superior sobre evasão, reprovações e estratégias preventivas. Avaliação, 21(1), 125-151. https://doi.org/10.1590/S1414-40772016000100007.

[20] Dore, R. (2013). Evasão e competência na rede federal de educação profissional. Maceió: CAPES/INEP.

[21] Faria, R. M. O. et al. (2017). O sentido da relação trabalho e saúde. Physis Revista de Saúde Coletiva, 27(3), 541-559. https://doi.org/10.1590/S0103-73312017000300009.

[22] Fernandes, E. F. (2018). O fenômeno da evasão discente: estudo multicaso nos programas de pós-graduação em administração do estado de Santa Catarina. Unpublished master thesis, Universidade Federal de Santa Catarina, Santa Catarina, Brazil.

[23] Freschi, E. M., \& Freschi M. (2013). Relações interpessoais: a construção do espaço artesanal no ambiente escolar. Revista de Educação Ideau, 8(18).

[24] Gonçalves, M. E. et al. (2010). Fatores determinantes da qualidade do ensino nas escolas de Minas Gerais: uma análise para a 4a série do ensino fundamental. Annals of the Encontro Nacional de Estudos Populacionais, Caxambu, Brazil.

[25] Kanan, L. A., \& Zanelli, J. C. (2011). Características do trabalho de coordenadores de curso no contexto universitário. Revista Espaço Pedagógico, 18(1), 151-170. https://doi.org/10.5335/rep.2013.2072

[26] Ketokivi, M., \& Choi, T. (2014). Renaissance of case research as a scientific method. Journal of Operations Management, 32, 232240. https://doi.org/10.1016/j.jom.2014.03.004

[27] Kowarick, L. (2003). Sobre a vulnerabilidade socioeconômica e civil: Estados Unidos, França e Brasil. RBCS, 18(51), 61-85. https://doi.org/10.1590/S0102-69092003000100006.

[28] Lisboa, C. (2015). Uma lupa para diagnosticar as desigualdades. Desafios do desenvolvimento, 12(85), 42-52.

[29] Lhuilier, D. (2014). Introdução à psicossociologia do trabalho. Cadernos de psicologia social do trabalho, 17, 520. https://doi.org/10.11606/issn.1981-0490.v17ispe1p5-19

[30] Machado, J. A. et al. (2014). A formação continuada de professores em serviço na perspectiva da abordagem ecológica do desenvolvimento humano. Revista Contrapontos, 14(3), 512-526. https://doi.org/10.14210/contra-pontos.v14n3.p512-526.

[31] Martadiani, A. M., Aziz, I. S. A., \& Widari, D. A. N. (2021). The influency of lecturer competence, self-efficacy and motivation on student achievement of the faculty of economics and business, Warmadewa University". International Journal of Science and Management Studies, 4(4), 52-59. https://doi.org/10.51386/25815946/ijsms-v4i4p106.

[32] Mattos, E., \& Chaves, A. M. (2010). Trabalho e escola: é possível conciliar? a perspectiva de jovens aprendizes baianos. Psicologia: Ciência e Profissão, 30(3), 540-555. https://doi.org/10.1590/S1414-98932010000300008

[33] Melo, S. L., \& Borges, L. (2007). O. A transição da universidade ao mercado de trabalho na ótica jovem. Psicologia: Ciência e Profissão, 27(3), 376-395.

[34] Monteiro, S. R. R. P. (2011). O marco conceitual da vulnerabilidade social. Sociedade em Debate, 17(2), 29-40.

[35] Nascimento-e-Silva, D. (2012). Manual de redação para trabalhos acadêmicos: position paper, ensaios teóricos, artigos científicos, questões discursivas. São Paulo: Atlas. 
DOI: $\underline{10.51386 / 25815946 / \mathrm{ijsms}-\mathrm{v} 4 \mathrm{i} 4 \mathrm{p} 127}$

Volume: 4 Issue: 4

July to August 2021

https://www.ijsmsjournal.org

[36] Nascimento-e-Silva, D. (2017). Gestão de organizações de ciência e tecnologia: ferramentas e procedimentos básicos. Saarbrücken: Novas Edições Acadêmicas.

[37] Nascimento-e-Silva, D. (2020). Manual do método científico-tecnológico: versão sintética. Florianópolis: DNS Editor.

[38] Nascimento-e-Silva, D. et al. (2013). Proposição de uma sistemática de avaliação de aprendizagem na formação de administradores com base no processo gerencial. Rev. Adm. UFSM, 6(4), 640-657. https://doi.org/10.5902/198346595826.

[39] Nha, N. T., \& Yen, P. H. (2021). The effects of teacher's use of interactional strategies of EFL students' speaking performance. International Journal of Science and Management Studies, 4(4), 152-166. https://doi.org/10.51386/25815946/ijsms-v4i4p115.

[40] Oliveira, E. S. (2019). Criação de um portfólio de cursos de extensão para o Campus Itaituba da Universidade Federal do Oeste do Pará. Unpuplished Master thesis, Instituto Federal de Educação, Ciência e Tecnologia do Amazonas, Manaus, Brazil.

[41] Palermo, G. A. et al. (2014). Fatores associados ao desempenho escolar. Revista Brasileira de Estudos de População, 31 (2), $367-394$. https://doi.org/10.1590/S0102-30982014000200007

[42] Pinheiro, M. R. (2007). O que posso fazer por mim? Ou a outra face da Pedagogia do Ensino Superior: Princípios e desafios das boas práticas dos estudantes. Annals of the IX Congresso da Sociedade Portuguesa das Ciências da Educação: Educação para o Sucesso, Políticas e Actores. Funchal, Portugal.

[43] Saltini, C. J. P. (2008). Afetividade e inteligência. Rio de Janeiro: Wak.

[44] Silva, R.O. (2019). Proposta de autocapacitação para coordenadores de graduação. Unpublished master thesis, Instituto Federal de Educação, Ciência e Tecnologia do Amazonas, Manaus, Brazil.

[45] Silva, R.O. et al. (2019). O ciclo PDCA como proposta para uma gestão escolar. Revista de Gestão e Avaliação Educacional, 8(17), 1-13. http://dx.doi.org/10.5902/2318133836102.

[46] Silva, R. O., \& Nascimento-e-Silva, D. (2020). Impactos do novo Coronavírus nas organizações e as inovações no mundo do trabalho, saúde e educação. Annals of the XI Colóquio Organizações, Desenvolvimento e Sociedade. Universidade da Amazônia, Belém, November 10 to 11 , p. 1-21.

[47] Silva, R. O. et al. (2019). Tópicos essenciais na construção de questionários de pesquisa. Annals of the IX Simpósio de Educação em Ciências na Amazônia. Universidade do Estado do Amazonas, October 9 to 11, p. 505-509.

[48] Silveira, H. (2010). Estudo da degradação e do impacto sócio-ambiental na Bacia do Córrego Osório, Maringá - Paraná. Revista Geografar Curitiba, 5(1), 176-205. http://dx.doi.org/10.5380/geografar.v5i1.17788

[49] Soares, T. M. (2005). Modelo de três níveis hierárquicos para proficiência dos alunos de 4a série avaliados no teste de língua portuguesa do SIMAVE/PROEB-2002. Revista Brasileira de Educação, (29), 73-87.

[50] Souza, S. S. (2020). Criação do curso de extensão “Conhecendo a Indústria 4.0 Sob o Olhar da Ciência”. Unpublished master thesis, Instituto Federal de Educação, Ciência e Tecnologia do Amazonas, Manaus, Brazil.

[51] Souza, E., \& Freitas, L. F. (2021). Um estudo sobre a evasão nos cursos de graduação dos institutos federais. Revista Brasileira de Educação Profissional e Tecnológica, 1(20), 1-16. https://doi.org/10.15628/rbept.2021.10757

[52] Thomé, L. D. et al. (2016). O desafio de conciliar trabalho e escola: características sociodemográficas de jovens trabalhadores e não-trabalhadores. Psicologia: Teoria e Pesquisa, 32(1), 101-109. http://dx.doi.org/10.1590/0102-37722016011944101109.

[53] Tiecher, A. L. et al. (2019). Formação do professor para a educação superior em eventos nacionais (2014-2016). Revista Internacional Educação Superior, 6, 1-28. https://doi.org/10.20396/riesup.v6i0.8654785

[54] Tonelotto, J. M. F. et al. (2005). Avaliação do desempenho escolar e habilidades básicas de leitura em escolares do ensino fundamental. Avaliação Psicológica, 4(1), 33-43.

[55] Valle, M. R. L., Nascimento-e-Silva, D., \& Silva, R. O. (2020). Avaliação participativa nos espaços pedagógicos: análise de uma instituição escolar do Norte do Brasil. Revista de Gestão e Avaliação Educacional, 9(18), 1-17. http://dx.doi.org/10.5902/2318133840714.

[56] Zago, N. (2006). Do acesso à permanência no ensino superior: percursos de estudantes universitários de camadas populares Revista Brasileira de Educação, 11(32), 226-237. 